\title{
Diabetogenic Action of Alloxan-Like Compounds: The Effect of Dehydrouramil Hydrate Hydrochloride on Isolated Islets of Langerhans of the Rat
}

\author{
S.P.C. Tait ${ }^{1}$, M. Poje $^{2}$, B. Rocic ${ }^{3}$ and S.J.H. Ashcroft ${ }^{1}$ \\ ${ }^{1}$ Nuffield Department of Clinical Biochemistry, John Radcliffe Hospital, Oxford, UK, ${ }^{2}$ Laboratory of Organic Chemistry, Faculty of Science and \\ ${ }^{3}$ Institute for Diabetes, Endocrinology and Metabolic Diseases "Vuk Vhrovac", Medical Faculty, University of Zagreb, Yugoslavia
}

\begin{abstract}
Summary. Dehydrouramil hydrate hydrochloride (DHU) is an analogue of alloxan which retains the in vivo diabetogenic activity of alloxan but, in contrast to alloxan, is stable in aqueous media at physiological $\mathrm{pH}$. Using rat islets of Langerhans, we have studied the acute effects of DHU on B cell function. Glucose-stimulated insulin release was markedly inhibited by DHU, the concentration of DHU giving 50\% inhibition $\left(\mathrm{I}_{50}\right)$ was $1 \mathrm{mmol} / 1$; this was lowered to $0.5 \mathrm{mmol} / 1$ when the islets were exposed to $\mathrm{DHU}$ for $5 \mathrm{~min}$ before elevation of glucose concentration. The basis for this change appeared to be a protective effect of glucose, since the inclusion of 3-0-methylglucose during pre-incubation with DHU also attenuated the subsequent inhibition of glucose-stimulated insulin release. The inhibitory effect on glucose-stimulated insulin release of a 5-min exposure to DHU persisted throughout a subsequent 120-min period in the absence of DHU. DHU also inhibited insulin release stimulated by mannose $(20 \mathrm{mmol} / \mathrm{l})$ or by 2-ketoisocaproate $(20 \mathrm{mmol} / 1)$ with $\mathrm{I}_{50}$ of 1 and $0.5 \mathrm{mmol} / 1 \mathrm{re}$ -
\end{abstract}

spectively. Concentrations of DHU up to $1 \mathrm{mmol} / 1 \mathrm{had}$ no significant effect on islet glucose oxidation or ATP content; $5 \mathrm{mmol} / \mathrm{l} \mathrm{DHU}$ did not affect the rate of glucose oxidation, but lowered the ATP content by $30 \%$ without pre-incubation and by $60 \%$ in islets pre-incubated for $5 \mathrm{~min}$ with. DHU before addition of glucose. Inhibitory effects of DHU were also found on rates of incorporation of $\left[{ }^{3} \mathrm{H}\right]$-leucine into insulin plus proinsulin and into total islet protein; however, these parameters were less sensitive to DHU than was insulin release. These effects of DHU were similar to those of alloxan. These data suggest that DHU is an important new tool for studying the mechanism of action of $\mathrm{B}$ cell cytotoxic agents; in addition, the fact that DHU is a potential metabolite of uric acid could have relevance to the aetiology of diabetes mellitus.

Key words: Dehydrouramil hydrate hydrochloride, alloxan, diabetes, islets of Langerhans, insulin secretion.
Although the selective destruction of B cells produced by alloxan has been a useful tool in diabetic research since its discovery [1], the precise way in which alloxan interacts with the B cell remains a matter for debate [2]. Over 30 years ago it was first suggested that an alloxanlike molecule could conceivably play a part in the aetiology of human diabetes [1]: in view of the chemical relationship of alloxan to uric acid, the possibility exists that alloxan or a structurally related compound could arise in the body consequent to some disturbance of purine or pyrimidine metabolism. The marked instability of alloxan in aqueous media at physiological $\mathrm{pH}$ (halflife at $37^{\circ} \mathrm{C}$ is about $1 \mathrm{~min}$ ) poses problems in investigations of such a biogenetic hypothesis for diabetes and also complicates study of the mechanism of action of alloxan. Recently, it was shown that, in common with other nucleophiles, ureas, amides and ammonium salts react with the 5-carbonyl of alloxan to give the corresponding hemiaminal derivatives which are very much more stable than the parent alloxan but retain diabetogenic action in vivo [3]. A particularly potent derivative is 5-amino-5-hydroxy-2,4,6-pyrimidinetrione hydrochloride (dehydrouramil hydrate hydrochloride; DHU) whose structure is shown in Figure $1[4,5]$. DHU is potentially formable from uric acid by known reactions<smiles></smiles>

Fig. 1. Structure of dehydrouramil hydrate hydrochloride 
Table 1. Effects of DHU on glucose-stimulated insulin release

\begin{tabular}{|c|c|c|c|c|}
\hline \multirow{3}{*}{$\begin{array}{l}\text { DHU } \\
\text { concentration } \\
(\mathrm{mmol} / \mathrm{l})\end{array}$} & \multicolumn{4}{|c|}{ Insulin release } \\
\hline & \multicolumn{2}{|c|}{ Without pre-incubation } & \multicolumn{2}{|c|}{ With pre-incubation } \\
\hline & $\begin{array}{l}\left(\mu \mathrm{U} \cdot \text {. } \text { islet }^{-1} .\right. \\
\left.\mathrm{h}^{-1}\right)\end{array}$ & $\begin{array}{l}(\% \text { of } \\
\text { control) }\end{array}$ & $\begin{array}{l}\left(\mu \mathrm{U} \cdot \text { islet }^{-1}\right. \\
\left.\mathrm{h}^{-1}\right)\end{array}$ & $\begin{array}{l}(\% \text { of } \\
\text { control) }\end{array}$ \\
\hline 0 & $535 \pm 40$ & 100 & $686 \pm 43$ & 100 \\
\hline 0.1 & $564 \pm 71$ & $105 \pm 13$ & $635 \pm 70$ & $93 \pm 10$ \\
\hline 0.25 & - & - & $474 \pm 55^{\mathrm{a}}$ & $69 \pm 8$ \\
\hline 0.5 & $411 \pm 66$ & $77 \pm 11$ & $314 \pm 46^{\mathrm{c}}$ & $46 \pm 7$ \\
\hline 0.75 & $360 \pm 30^{b}$ & $67 \pm 6$ & - & - \\
\hline 1.0 & $299 \pm 24^{c}$ & $56 \pm 5$ & $98 \pm 11^{c}$ & $14 \pm 2$ \\
\hline 5.0 & $29 \pm 5^{c}$ & $5 \pm 1$ & - & - \\
\hline
\end{tabular}

Results are given as mean \pm SEM. For each condition, five batches of five islets were studied. For experiments without pre-incubation, islets were incubated for $2 \mathrm{~h}$ with $20 \mathrm{mmol} / \mathrm{l}$ glucose and in the absence or presence of DHU at the concentrations given. In experiments with pre-incubation, islets were incubated with or without DHU for $5 \mathrm{~min}$ in the absence of glucose before addition of glucose: incubation was then continued for $2 \mathrm{~h} .{ }^{\mathrm{a}} p<0.05 ;{ }^{\mathrm{b}} p<0.01 ;{ }^{\mathrm{c}} p<0.001$

shown in Figure 2. It has been shown in vivo that persistent hyperglycaemia was established within $30 \mathrm{~min}$ of a single dose of DHU $(75 \mathrm{mg} / \mathrm{kg})$ and morphological changes were found which in rapidity and magnitude were greater than with an equivalent dose of alloxan [5]. The present study is the first investigation of the action of DHU in vitro: we demonstrate that DHU is a potent inhibitor of acute insulin release from islets of Langerhans and document effects of DHU on other parameters of islet function.

\section{Materials and Methods}

\section{Materials}

DHU was synthesized as described previously [5]. Collagenase and albumin were supplied by Sigma, London, UK and all radiochemicals were from the Radiochemical Centre, Amersham, Bucks, UK. Other chemicals of the purest available grade were from British Drug Houses, Poole, Dorset, UK. Rat insulin standard was a gift from Dr. AJ Moody, Novo Research Laboratories, Copenhagen, Denmark.

\section{Preparation of Islets of Langerhans}

Islets were prepared by a collagenase method [6] from the pancreases of male Wistar rats fed ad libitum on standard laboratory diet (E. Dixon \&Sons, Ware, Herts, UK). Islets were harvested by a wire-loop under a dissecting microscope and incubated in bicarbonate medium [7] as described below. Two different protocols were used to test the effects of DHU. In the first, incubation was carried out for $120 \mathrm{~min}$ with the stimulant stated and in the presence or absence of various concentrations of DHU. In the second, islets were preincubated for $5 \mathrm{~min}$ with or without DHU before addition of stimulant: incubation was then continued for $120 \mathrm{~min}$.

\section{Insulin Release}

Batches of five islets were incubated at $37^{\circ} \mathrm{C}$ in $0.6 \mathrm{ml}$ bicarbonate medium containing $2 \mathrm{~g} / 1$ of albumin and the additions stated in the
Table 2. Inhibition of glucose-stimulated insulin release by DHU: effects of 3-0-methylglucose and of limited exposure to DHU

\begin{tabular}{|c|c|c|c|c|c|c|}
\hline & \multirow{2}{*}{\multicolumn{2}{|c|}{$\begin{array}{l}\text { Pre-incubation } \\
\text { conditions }\end{array}$}} & \multicolumn{3}{|c|}{ Incubation conditions } & \multirow{3}{*}{$\begin{array}{l}\text { Insulin } \\
\text { release } \\
(\mu \mathrm{U} / \cdot \\
\left.\text { islet }^{-1} \cdot \mathrm{h}^{-1}\right)\end{array}$} \\
\hline & & & \multirow{2}{*}{$\begin{array}{l}\text { DHU } \\
(1 \\
\mathrm{mmol} / \mathrm{l})\end{array}$} & \multirow{2}{*}{\multicolumn{2}{|c|}{$\begin{array}{ll}\text { 3-0-meth-yl- Glucose } \\
\text { glucose }(20 \\
\text { mmol/1) } & (20 \\
& \mathrm{mmol} / \mathrm{l})\end{array}$}} & \\
\hline & $\begin{array}{l}\text { DHU } \\
(1 \\
\text { mmol/l) }\end{array}$ & $\begin{array}{l}\text { 3-0-meth-yl- } \\
\text { glucose }(20 \\
\text { mmol/1) }\end{array}$ & & & & \\
\hline \multicolumn{7}{|l|}{$\begin{array}{l}\text { Experi- } \\
\text { ment } 1\end{array}$} \\
\hline & - & - & - & - & + & $589 \pm 84$ \\
\hline & + & - & + & - & + & $45 \pm 6$ \\
\hline & + & + & + & + & + & $313 \pm 28$ \\
\hline & - & + & - & + & + & $543 \pm 35$ \\
\hline \multirow[t]{5}{*}{$\begin{array}{l}\text { Experi- } \\
\text { ment } 2\end{array}$} & & & & & & . \\
\hline & - & - & - & - & + & $443 \pm 18(4)$ \\
\hline & + & - & - & - & + & $32 \pm 3(4)$ \\
\hline & + & + & - & - & + & $245 \pm 30$ \\
\hline & - & + & - & - & + & $465 \pm 56$ \\
\hline
\end{tabular}

In experiment 1 , islets were pre-incubated for 5 min and then incubated for $2 \mathrm{~h}$ with the additions shown. In experiment 2 , islets were washed after the incubation period. Results are given as mean $\pm \mathrm{SEM}$ for five batches of islets except where otherwise stated

text or tables. Insulin released into the medium was measured by a charcoal-binding radioimmunoassay [8] using rat insulin as standard.

\section{Insulin Biosynthesis}

The rates of biosynthesis of insulin plus proinsulin and of total protein were measured by incubation of islets with $\left\{4,5-{ }^{3} \mathrm{H}\right\}$-leucine as previously described in detail [9].

\section{Islet ATP Content}

The islet content of ATP was measured by a luciferase method after incubation of islets under various conditions in the presence or absence of DHU as detailed elsewhere [10].

\section{Islet Glucose Oxidation}

Batches of ten islets were incubated with $\left\{\mathrm{U}-{ }^{14} \mathrm{C}\right\}$-glucose under the conditions stated and glucose oxidation measured as the formation of ${ }^{14} \mathrm{CO}_{2}$. The technique has been previously described in detail [11].

\section{Statistical Analysis}

Data are given as mean \pm SEM and the differences were analysed with Student's t-test.

\section{Results}

\section{Effects of DHU on Insulin Release}

The stimulatory effect of glucose $(20 \mathrm{mmol} / 1)$ on insulin release was inhibited by the simultaneous presence of DHU (Table 1). Significant inhibition was achieved with $0.5 \mathrm{mmol} / 1 \mathrm{DHU}$ and the concentration of $\mathrm{DHU}$ giving $50 \%$ inhibition $\left(\mathrm{I}_{50}\right)$ was approximately $1 \mathrm{mmol} / \mathrm{l}$. Pre-incubation of islets with DHU for $5 \mathrm{~min}$ 
Table 3. Effects of DHU on insulin release stimulated by 2-ketoisocaproate or mannose

\begin{tabular}{|c|c|c|c|c|}
\hline \multirow{2}{*}{$\begin{array}{l}\mathrm{DHU} \\
\text { concentration } \\
(\mathrm{mmol} / \mathrm{l})\end{array}$} & \multirow{2}{*}{$\begin{array}{l}\text { Mannose } \\
(20 \mathrm{mmol} / \mathrm{l})\end{array}$} & \multirow{2}{*}{$\begin{array}{l}\text { 2-Ketoiso- } \\
\text { caproate } \\
(20 \mathrm{mmol} / \mathrm{l})\end{array}$} & \multicolumn{2}{|l|}{ Insulin release } \\
\hline & & & $\begin{array}{l}\left(\mu \mathrm{U} \cdot \text { islet }^{-1}\right. \\
\left.\mathrm{h}^{-1}\right)\end{array}$ & $\begin{array}{l}\text { (\% of } \\
\text { control) }\end{array}$ \\
\hline 0 & + & - & $260 \pm 27$ & 100 \\
\hline 0.25 & + & - & $212 \pm 16$ & $81 \pm 8$ \\
\hline 0.5 & + & - & $209 \pm 12$ & $72 \pm 6$ \\
\hline 1.0 & + & - & $125 \pm 12^{a}$ & $48 \pm 5$ \\
\hline 5.0 & + & - & $37 \pm 8^{a}$ & $14 \pm 3$ \\
\hline 0 & - & + & $194 \pm 12$ & 100 \\
\hline 0.25 & - & + & $119 \pm 15$ & $63 \pm 7$ \\
\hline 0.5 & - & + & $100 \pm 10^{\mathrm{b}}$ & $51 \pm 5$ \\
\hline 1.0 & - & + & $27 \pm 6^{b}$ & $14 \pm 3$ \\
\hline
\end{tabular}

Results are given as mean \pm SEM. For each condition, five batches of five islets were incubated with mannose or 2-ketoisocaproate in the absence or presence of DHU for $2 \mathrm{~h} .{ }^{\mathrm{a}} p<0.01 ;^{\mathrm{b}} p<0.001$

Table 4. Effects of DHU on the biosynthesis of insulin plus proinsulin and of total islet protein

\begin{tabular}{|c|c|c|c|c|}
\hline \multirow{3}{*}{$\begin{array}{l}\mathrm{DHU} \\
\text { concentra- } \\
\text { tion } \\
(\mathrm{mmol} / \mathrm{l})\end{array}$} & \multicolumn{4}{|c|}{$\begin{array}{l}\text { Incorporation of }\left\{{ }^{3} \mathrm{H}\right\} \text {-leucine into islet protein and insulin plus } \\
\text { proinsulin }(\mathrm{dpm})\end{array}$} \\
\hline & \multicolumn{2}{|c|}{ Without pre-incubation } & \multicolumn{2}{|c|}{ With pre-incubation } \\
\hline & $\begin{array}{l}\text { Insulin } \\
+ \text { proinsulin }\end{array}$ & Total protein & $\begin{array}{l}\text { Insulin } \\
+ \text { proinsulin }\end{array}$ & Total protein \\
\hline 0 & $8143 \pm 758$ & $81987 \pm 6219$ & $7097 \pm 605$ & $71426 \pm 4273$ \\
\hline 0.1 & $8292 \pm 397$ & $77979 \pm 5799$ & $6343 \pm 703$ & $77466 \pm 8618$ \\
\hline 0.5 & $7181 \pm 678$ & $80490 \pm 5579$ & $5383 \pm 333^{\mathrm{a}}$ & $69423 \pm 5045$ \\
\hline 1.0 & $6521 \pm 476$ & $82392 \pm 5100$ & $4353 \pm 188^{b}$ & $58510 \pm 2729^{a}$ \\
\hline 5.0 & $782 \pm 180(7)^{c}$ & $27645 \pm 2530^{c}$ & $315 \pm 136(6)^{\mathrm{c}}$ & $15769 \pm 3321^{\mathrm{c}}$ \\
\hline
\end{tabular}

Results are given as mean \pm SEM for eight batches of seven islets except where indicated otherwise. dpm: disintegrations per minute. ${ }^{\mathrm{a}} p<0.05 ;{ }^{\mathrm{b}} p<0.01 ;{ }^{\mathrm{c}} p<0.001$

Table 5. Effects of DHU on islet glucose oxidation and ATP content

\begin{tabular}{|c|c|c|c|c|}
\hline \multirow{2}{*}{$\begin{array}{l}\text { DHU } \\
\text { concentra- } \\
\text { tion } \\
(\mathrm{mmol} / \mathrm{l})\end{array}$} & \multicolumn{2}{|c|}{ Without pre-incubation } & \multicolumn{2}{|c|}{ With pre-incubation } \\
\hline & $\begin{array}{l}\text { Glucose } \\
\text { oxidation } \\
{\text { (pmol } \cdot \text { islet }^{-1} \text {. }}_{\mathrm{h}^{-1} \text { ) }}\end{array}$ & $\begin{array}{l}\text { ATP content } \\
\text { (pmol/islet) }\end{array}$ & $\begin{array}{l}\text { Glucose } \\
\text { oxidation } \\
\left({\text { pmol } \cdot \text { islet }^{-1} \text {. }}_{\left.\mathrm{h}^{-1}\right)}\right.\end{array}$ & $\begin{array}{l}\text { ATP content } \\
\text { (pmol/islet) }\end{array}$ \\
\hline 0 & $36.7 \pm 4.0(12)$ & $9.5 \pm 0.2(14)$ & $35.5 \pm 7.7(16)$ & $8.9 \pm 0.3(8)$ \\
\hline 0.1 & $35.4 \pm 4.2(10)$ & $10.3 \pm 0.4(16)$ & $34.9 \pm 9.7(16)$ & $9.2 \pm 0.5(8)$ \\
\hline 0.5 & $37.8 \pm 5.2(10)$ & $9.9 \pm 0.1(16)$ & $34.2 \pm 6.0(16)$ & $8.1 \pm 0.4(8)$ \\
\hline 1.0 & $43.5 \pm 4.6(12)$ & $9.6 \pm 0.6(15)$ & $33.2 \pm 10.6(16)$ & $8.0 \pm 0.7(8)$ \\
\hline 5.0 & $42.3 \pm 3.9(12)$ & $6.7 \pm 0.4(15)^{\mathrm{a}}$ & $38.3 \pm 9.3(15)$ & $3.5 \pm 0.2(8)^{\mathrm{a}}$ \\
\hline
\end{tabular}

Results are given as mean \pm SEM for the number of batches of islets in parentheses. The glucose concentration was $20 \mathrm{mmol} / 1$ during all incubations, which were for $2 \mathrm{~h} .{ }^{a} p<0.001$

in the absence of glucose markedly enhanced the inhibitory effects of $\mathrm{DHU}, \mathrm{I}_{50}$ being reduced to $0.5 \mathrm{mmol} / \mathrm{l}$. The inhibitory effect of pre-incubation with $1 \mathrm{mmol} / 1$ DHU was markedly attenuated by the presence of 3-0methylglucose $(20 \mathrm{mmol} / \mathrm{l})$ during the pre-incubation and incubation periods (Table 2). Table 2 also shows that when islets pre-incubated with $1 \mathrm{mmol} / 1 \mathrm{DHU}$ for $5 \mathrm{~min}$ were washed to remove inhibitor before incuba- tion with glucose, the inhibition was not diminished, i. e. inhibition was irreversible. However, the protective effect of 3-0-methylglucose was still apparent with this protocol. Insulin release stimulated by mannose or by 2-ketoisocaproate was also inhibited by DHU (Table 3).

\section{Effects of DHU on Insulin Plus Proinsulin and Total Protein Biosynthesis}

The effects of DHU on the incorporation of $\left\{{ }^{3} \mathrm{H}\right\}$-leucine into total islet protein and into insulin plus proinsulin in the presence of $20 \mathrm{mmol} / 1$ glucose are shown in Table 4. Without preincubation, concentrations of DHU up to $1 \mathrm{mmol} / 1$ produced no significant inhibition of protein or insulin plus proinsulin biosynthesis. At a concentration of $5 \mathrm{mmol} / \mathrm{l}$, however, DHU inhibited markedly both parameters, reducing insulin plus proinsulin biosynthesis by over $90 \%$ and total protein biosynthesis by $66 \%$. Pre-incubation for $5 \mathrm{~min}$ with DHU in the absence of glucose increased the inhibitory potency so that significant inhibition of both parameters was seen with $1 \mathrm{mmol} / 1 \mathrm{DHU}$ (39\% inhibition of insulin plus proinsulin and $18 \%$ inhibition of total protein synthesis) and the effects of $5 \mathrm{mmol} / 1 \mathrm{DHU}$ were augmented (insulin plus proinsulin biosynthesis was essentially abolished and total protein synthesis was inhibited by $78 \%$ ).

\section{Effects of DHU on Islet Metabolism (Table 5)}

The rate of formation of ${ }^{14} \mathrm{C}_{2}$ from $\left\{\mathrm{U}_{-}{ }^{14} \mathrm{CO}_{2}\right\}$ glucose by islets at a glucose concentration of $20 \mathrm{mmol} / 1$ was not significantly affected by DHU at concentrations up to $5 \mathrm{mmol} / 1$ whether or not islets were pre-incubated with DHU. Islet ATP content was unaffected by DHU at concentrations up to $1 \mathrm{mmol} / 1$ but was decreased significantly by $5 \mathrm{mmol} / 1 \mathrm{DHU}$; the latter effect was enhanced by pre-incubation with DHU in the absence of glucose.

\section{Comparison with Effects of Alloxan}

The effects of DHU were compared with those of alloxan. Alloxan inhibited insulin release stimulated by $20 \mathrm{mmol} / 1$ glucose and the inhibition was accentuated if the islets were pre-incubated with alloxan before addition of glucose (Table 6). The dose-dependence was similar to that found for DHU. Insulin and protein biosynthesis were also inhibited by alloxan. Significant inhibition required $1 \mathrm{mmol} / 1$ alloxan in the absence of pre-incubation but less than $0.5 \mathrm{mmol} / 1$ in islets preincubated with alloxan. Islet glucose oxidation and ATP content were unaffected by alloxan at concentrations up to $1 \mathrm{mmol} / 1$ whether or not the islets were preincubated with the drug; for islets pre-incubated with $5 \mathrm{mmol} / 1$ alloxan, ATP content and glucose oxidation rate were decreased by $38 \%$ and $45 \%$, respectively. Table 7 shows that, as for DHU, the inhibitory effect of 
<smiles>O=c1[nH]c(=O)c2[nH]c(=O)[nH]c2[nH]1</smiles>

Uric acid<smiles>NC1C(=O)NC(=O)NC1=O</smiles>

Uramil<smiles>O=C1NC(=O)C(=N[Cl+]Cl)C(=O)N1</smiles>

DHU hydrochloride<smiles>[TeH4]</smiles><smiles>C[Hg]C</smiles><smiles>C1CCOCC1</smiles><smiles>O=C1NC(=O)C2(O)NC(=O)NC2(O)N1</smiles>

Uric acid glycol<smiles>Nc1ccccc1</smiles><smiles>NC(=O)NC1(N)C(=O)NC(=O)NC1=O</smiles>

5-Amino-pseudouric acid<smiles>NC(=O)NC1(O)C(=O)NC(=O)NC1=O</smiles>

5-Hydoxy-pseudouric acid<smiles>[CH]=C=C</smiles><smiles>NCC(=O)CN</smiles>

Alloxan Urea<smiles>O=C1NC(=O)C(O)(N[Cl+3])C(=O)N1</smiles>

DHU hydrochloride hydrate

Fig. 2. Synthetic routes to dehydrouramil hydrate hydrochloride

Table 6. Effects of alloxan on islet function

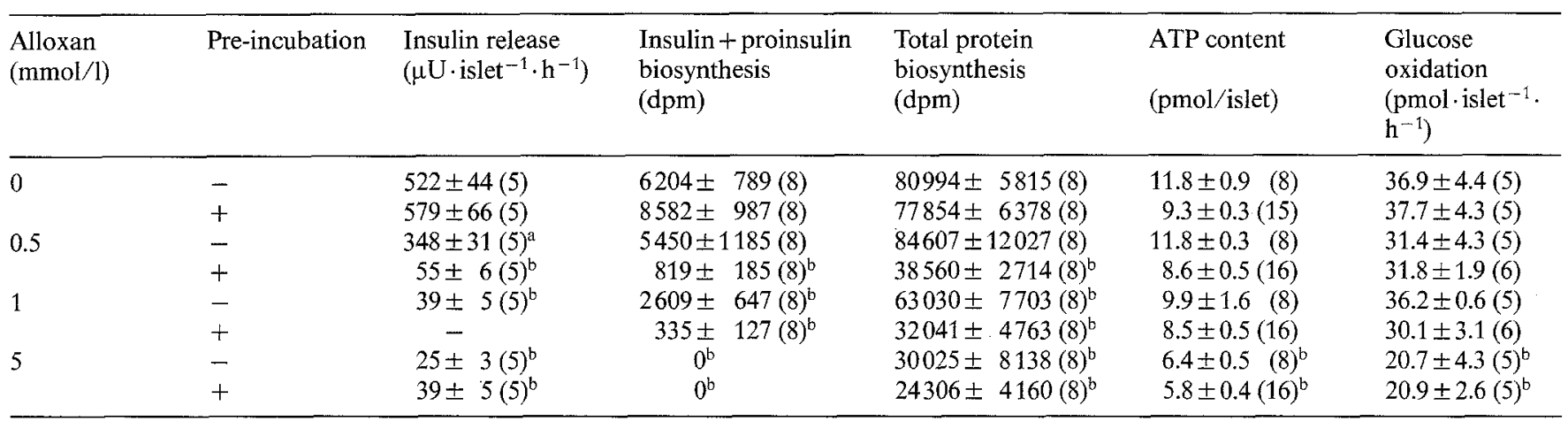

Data are given as mean \pm SEM for the number of batches of islets in parentheses. dpm: disintegrations per minute. ${ }^{\mathrm{a}} p<0.01 ;{ }^{\mathrm{b}} p<0.001$

alloxan on glucose-stimulated insulin release could be reversed by $3-0$-methylglucose.

\section{Discussion}

DHU can be formed chemically from uric acid. It retains the diabetogenic action of alloxan and is more potent than alloxan in vivo $[4,5]$ but is considerably more stable in aqueous solution than alloxan, showing no tendency to undergo rapid rearrangements involving nitrogen shift [4]. Thus, in the present experiments, we found that it was essential to prepare alloxan solutions immediately before use in order to see inhibitory effects, whereas solutions of DHU showed no loss of activity even after several hours.

The mechanism of action of alloxan has been exten-
Table 7. Protective effect of 3-0-methylglucose against the inhibition of glucose-stimulated insulin release by alloxan

\begin{tabular}{|c|c|c|c|c|c|}
\hline \multicolumn{2}{|c|}{ Pre-incubation conditions } & \multicolumn{3}{|c|}{ Incubation conditions } & \multirow{2}{*}{$\begin{array}{l}\text { Insulin } \\
\text { release } \\
(\mu \mathrm{U} \\
\text { islet }^{-1} \\
\left.\mathrm{~h}^{-1}\right)\end{array}$} \\
\hline $\begin{array}{l}\text { Alloxan } \\
(0.5 \mathrm{mmol} / \mathrm{l})\end{array}$ & $\begin{array}{l}\text { 3-0-methyl- } \\
\text { glucose } \\
(20 \mathrm{mmol} / \mathrm{l})\end{array}$ & $\begin{array}{l}\text { Alloxan } \\
(0.5 \\
\text { mmol/1) }\end{array}$ & $\begin{array}{l}\text { 3-0-methyl- } \\
\text { glucose } \\
(20 \\
\mathrm{mmol} / \mathrm{l})\end{array}$ & $\begin{array}{l}\text { Glucose } \\
(20 \\
\mathrm{mmol} / 1)\end{array}$ & \\
\hline \multicolumn{6}{|l|}{ Experiment 1} \\
\hline- & - & - & - & + & $662 \pm 49$ \\
\hline+ & - & + & - & + & $113 \pm 19$ \\
\hline+ & + & + & + & + & $297 \pm 19$ \\
\hline- & + & - & + & + & $678 \pm 34$ \\
\hline \multicolumn{6}{|l|}{ Experiment 2} \\
\hline- & - & - & - & + & $443 \pm 18$ \\
\hline+ & - & - & - & + & $37 \pm 11$ \\
\hline+ & + & - & - & + & $445 \pm 58$ \\
\hline - & + & - & - & + & $464 \pm 56$ \\
\hline
\end{tabular}

Results are given as mean \pm SEM for five batches of five islets. The protocols were similar to those given in the legend to Table 2 
sively studied [2]. The reaction of alloxan with aminoacids (the Strecker reaction) has been considered as has chelation of metal ions. Most evidence, however, has been adduced in favour of (a) reaction with important sulphydryl groups in the B cell [12] and (b) generation of toxic free radicals $[13,14]$. A model incorporating both the latter two mechanisms has been proposed [15]. The problem is complicated by uncertainty regarding the precise relationship between the acute effect of alloxan on insulin release in vitro and its chronic action in destroying B cells. Moreover, the basis for the relative specificity of alloxan for B cells is not apparent. The present study shows that DHU, a stable analogue of alloxan, produces a spectrum of acute effects on the B cell similar in many respects to that of alloxan itself. First, the release of insulin was more sensitive to DHU than other parameters tested; substantial inhibition of glucose-stimulated insulin release was achieved at a concentration ( $1 \mathrm{mmol} / \mathrm{l})$ of DHU that did not affect islet glucose oxidation or ATP content. Thus, a derangement of energy metabolism is not the primary cause for impairment of insulin release. Second, the impairment of release was not limited to that stimulated by glucose. Third, inhibition was manifest after a short exposure and persisted throughout subsequent incubation in the absence of inhibitor. Fourth, the presence of glucose or 3-0-methylglucose during the first $5 \mathrm{~min}$ of exposure of islets to DHU afforded protection against the inhibitory effect of DHU. The similarity of these responses of the islets to DHU to those seen with alloxan is clear both from the literature [2] and from our own studies with alloxan reported here.

In vivo, DHU was reported to be more potent than alloxan. However, the in vitro studies presented here show that the two drugs are of similar potency on the parameters tested. We ascribe this difference between the in vivo and in vitro findings to the relative stability of DHU and alloxan. The present studies have been confined to acute actions which require exposure of the islets to the drug for $5 \mathrm{~min}$ or less. Despite its instability compared to DHU, alloxan is sufficiently stable to exert its acute effects. In vivo, on the other hand, the hyperglycaemia and B-cell necrosis studied also involve the chronic action of the drugs to destroy $B$ cells; for the relatively slow onset of these effects the greater stability of DHU may enhance its potency relative to alloxan.

Further studies with DHU should clarify the mechanism by which alloxan-like cytotoxic agents interact with the B cell. In addition, the present findings offer a new perspective on the biogenetic hypothesis for the aetiology of diabetes mellitus. The possible formation of DHU from uric acid in vivo merits investigation.
Acknowledgements. These studies were supported by grants from the Medical Research Council and the British Diabetic Association.

\section{References}

1. Dunn JS, Sheehan HL, McLetchie NGB (1943) Nectosis of islets of Langerhans produced experimentally. Lancet 1: 484-487

2. Cooperstein SJ, Watkins D (1981) Action of toxic drugs on islet cells. In: Cooperstein SJ, Watkins D (eds) The islets of Langerhans. Biochemistry, physiology and pathology. Academic Press, New York, pp 387-425

3. Poje M, Rocic B (1979) A reinvestigation of alloxan-like compounds derived from uric acid. Tetrahedron Letts $49: 4781-4782$

4. Poje M, Rocic B, Skrabalo Z (1980) $\beta$-Cytotoxic action of alloxan and alloxan-like compounds derived from uric acid. Diabet Croat 9: $145-166$

5. Poje M, Rocic B, Sikirica M, Vickovic L, Bruvo M (1983) Oxidation of uric acid. 4. Synthesis, structure and diabetogenic activity of 2,4,6(1H,3H)-pyrimidinetrione-5-iminium salts and their alloxan-like covalent adducts. J Med Chem 26: 861-865

6. Coll-Garcia E, Gill JR (1969) Insulin release by isolated pancreatic islets of the mouse incubated in vitro. Diabetologia 5: 61-66

7. Krebs HA, Henseleit K (1932) Untersuchungen über die Harnstoffbildung im Tierkörper. Hoppe-Seylers Z Physiol Chem 210: $33-62$

8. Ashcroft SJH, Crossley JR (1975) The effects of glucose, N-acetylglucosamine, glyceraldehyde and other sugars on insulin release in vivo. Diabetologia 11:279-284

9. Ashcroft SJH, Crossley JR, Crossley PC (1975) The effect of $\mathrm{N}$-acylglucosamines on the biosynthesis and secretion of insulin in rat pancreatic islets. Biochem J 154: 701-707

10. Asheroft SJH, Weerasinghe LCC, Randle PJ (1973) Interrelationships of islet metabolism, adenosine triphosphate content and in sulin release. Biochem J 132: 223-231

11. Ashcroft SJH, Hedeskov CJ, Randle PJ (1970) Glucose metabolism in mouse pancreatic islets. Biochem $\mathbf{J}$ 118: 143-154

12. Watkins D, Cooperstein SJ, Fiel S (1979) Studies on the selectivity of alloxan for the $\beta$-cells of the islets of Langerhans: effect of $\mathrm{pH}$ on the in vitro action of alloxan. J Pharm Exp Therap 208: 184-189

13. Heikkila RE, Winston B, Cohen G, Barden H (1976) Alloxan-induced diabetes: evidence for hydroxyl radical as a cytotoxic intermediate. Biochem Pharmacol 25: 1085-1092

14. Grankvist K, Marlund S, Sehlin J, Taljedal I-B (1979) Superoxide dismutase, catalase and scavengers of hydroxyl radicals protect against the toxic action of alloxan on pancreatic islet cells in vitro. Biochem J 182: 17-25

15. Taljedal I-B (1981) On insulin secretion. Diabetologia 21: 1-17

Received: 14 January 1983

and in revised form: 30 May 1983

Dr. S.J.H. Ashcroft

Nuffield Department of Clinical Biochemistry

John Radcliffe Hospital

Headington

Oxford OX3 9DU

UK 